DOI https://doi.org/10.18551/rjoas.2017-06.29

\title{
STUDY ON AUDITOR'S ATTITUDE IN USING INFORMATION TECHNOLOGY FOR AUDITING: THEORY OF PLANNED BEHAVIOR AND SOCIAL COGNITIVE THEORY MODIFICATION
}

\author{
Areta Widya Kusumadewi*, Baridwan Zaki, Bambang Hariadi \\ Faculty of Economics and Business, University of Brawijaya, Indonesia \\ *E-mail: aretawidyakusumadewi93@gmail.com
}

\begin{abstract}
The objective of the study was to evaluate the factors that influenced behavior intention in auditor's behavior in using information technology for auditing. This study was a combination between Theory of Planned Behavior (TPB) model and Social Cognitive Theory (SCT) from previous studies. The data collection method was survey and the samples were 102 auditors who worked in the big four Public Accounting Firm in Indonesia. Partial Least Square (PLS) was used to analyze the data. The findings were the construct of attitude, subjective norm, perception of behavioral control, and self-belief positively affected the behavior intention. Furthermore, the behavioral had positive influence towards the auditor's behavior in using information technology for auditing. The implications of this study aret that providers of information technology for auditing and management should, again, pay attention to the attitudes, subjective norms, behavior control perceptions, self-beliefs, behavior intentions and behavior of auditors.
\end{abstract}

\section{KEY WORDS}

Auditor, information technology for auditing, theory of planned behavior, social cognitive theory.

Information technology is growing and getting more sophisticated from year to year. Information technology in the form of software can develop computerized system (Davis et al., 1989; Compeau \& Higgins, 1995). This type of information technology is used in several organizations, both public and governmental organizations.

This study discussed how auditors use information technology for auditing (IT for auditing). Information technology for auditing is the application or software used during the auditing process (Damasiotis, 2015). Information technology for auditing can assist auditors in storing files, saving amount of paper used, costs, and time (Stoel, Havelka, \& Merhout, 2012). In addition, the purpose the software or application is to detect an offense committed by an audited company (Stoel, Havelka, \& Merhout, 2012).

According to the International Federation of Accountants or IFAC (2006a), auditor should have knowledge and competence in using information technology due to development of business owned by public institutions. A lot of foreign companies and auditors come to Indonesia and as the consequence; Indonesian auditor should be technosavvy in order to compete. Pressure from the environment is another reason why auditors should be familiar with information technology for auditing (Stoel, Havelka, \& Merhout, 2012; Havelka \& Merhout, 2013).

Few years ago, a survey towards the implementation of information technology in Indonesia was conducted. Sugiarsono (2003) stated that Indonesia failed to apply approximately $75 \%$ of the information technology. Sugiarsono (2003) mentioned the failure stemmed from lack of planning and technical issues. Curry (2002) explained that human resource, process and work organization heavily influenced fail attempt to apply certain type of information technology. Ajzen (1991) postulated that poor implementation of information technology was the result of individual's hestation to use information technology.

Behavior is a real action performed by individuals (Davis et al., 1989; Ajzen, 1991; Kim et al., 2016). If individuals accept the use of information technology, then it can be said that the information technology has successfully been applied; on the other hand, if the individual 
refuses the use of information technology, the implementation of the technology failed (Ajzen, 1991). Once individual behavior has been described, we will figure out whether or not information technology has been applied successfully.

Several studies (Taylor \& Todd, 1995; Chen et al., 2013; Jafarkarimi et al., 2016, Cheung \& To, 2016) suggest that the main determinant of behavior is interest. Interest is an individual's desire to perform an action (Ajzen, 1991, Chen et al., 2013). Although interest is a key determinant of individual behavior, there are other factors that may affect interest, as described in Theory of Planned Behavior (TPB). Some studies on TPB (Armitage \& Conner, 2001; Lam, Cho, \& Qu, 2007; Baker \& White, 2010; Jafarkarimi et al., 2016; Kim et al., 2016; Cheung \& To, 2016) suggested that future studies added other variables that may affect the interests of individual behavior and they weresupposed to be conducted in different settings and cultures.

Gap between the study and previous studies is, based on the suggestions above, the researchers added one variable from Social Cognitive Theory (SCT), namely self-efficacy. The study involed several auditors who worked in the Big Four Public, an accounting firm in Indonesia, as the samples. The researchers decided to add self-efficacy because one of the characteristics of an auditor was to have high confidence (Damasiotis et al., 2015; IFAC, 2006a).

The study is the combination between TPB and SCT theories. The purpose of the study is to predict individual behavior in using information technology, more particularly information technology for auditing.

\section{LITERATURE REVIEW}

Information technology for Auditing (IT for Auditing). Information technology for auditing is a medium in the form of either software or application to use during auditing process (Kim, Maninno, \& Nieschwietz, 2009). Information technology for auditing can integrate all information related to auditing (Havelka \& Merhout, 2013). Some examples of information technology for auditing are Computer Assisted Audit Techniques (CAAT) including Audit Command Language (ACL) and Picalo, Powertech Compliance Assessment, and other softwares facilitating the auditing process.

Theory of Planned Behavior (TPB). TPB is a theory of individual behavior that is influenced by behavior intention (Ajzen, 1985). The interest of individual behavior is influenced by three independent variables, attitude, subjective norm, and perception of behavioral control (Ajzen, 1991). TPB can be used to predict certain behaviors in various situations, situations and different forms of action (Beck \& Ajzen, 1991). The basic assumption of TPB is that many behaviors are not all under the full control of the indiviual, so it is necessary to add the concept of behavioral perception control (Ajzen, 1991).

Social Cognitive Theory (SCT). SCT is a theory based on the concept of mutual relationships of personal factors, environment and individual behavior (Bandura, 1986). These three factors are interrelated (Bandura, 1986). SCT suggests that individual motivation and self-regulatory processes are controlled through several self-regulating mechanisms (Bandura, 1986, Bandura, 1999). Self-confidence is a key factor in determining whether an individual has sufficient ability to accomplish and complete the task. The SCT model was then developed by Compeau \& Higgins (1995). Compeau \& Higgins (1995) indicate that selfbelief influences individual behavior intentions before influencing behavior. In this study, selfefficacy is defined as the auditor's ability and conviction that he is capable of using information technology for auditing.

Research Model and Hypothesis Development:

Attitude is defined as a positive or negative feeling of an individual to perform the behavior (Davis et al., 1989; Ajzen, 1991; Kim et al., 2016; Cheung \& To, 2016). Several studies (Davis et al, 1989, Ajzen, 1991, Baker \& White, 2010, Jafarkarimi et al, 2016, Kim et al., 2016; Cheung \& To, 2016) suggest that attitudes have a positive effect on behavior intention of an individual. Therefore, the first hypothesis is: 
$\mathrm{H}_{1}$ : Attitude has positive influence towards behavior intention of auditor in using information technology for auditing

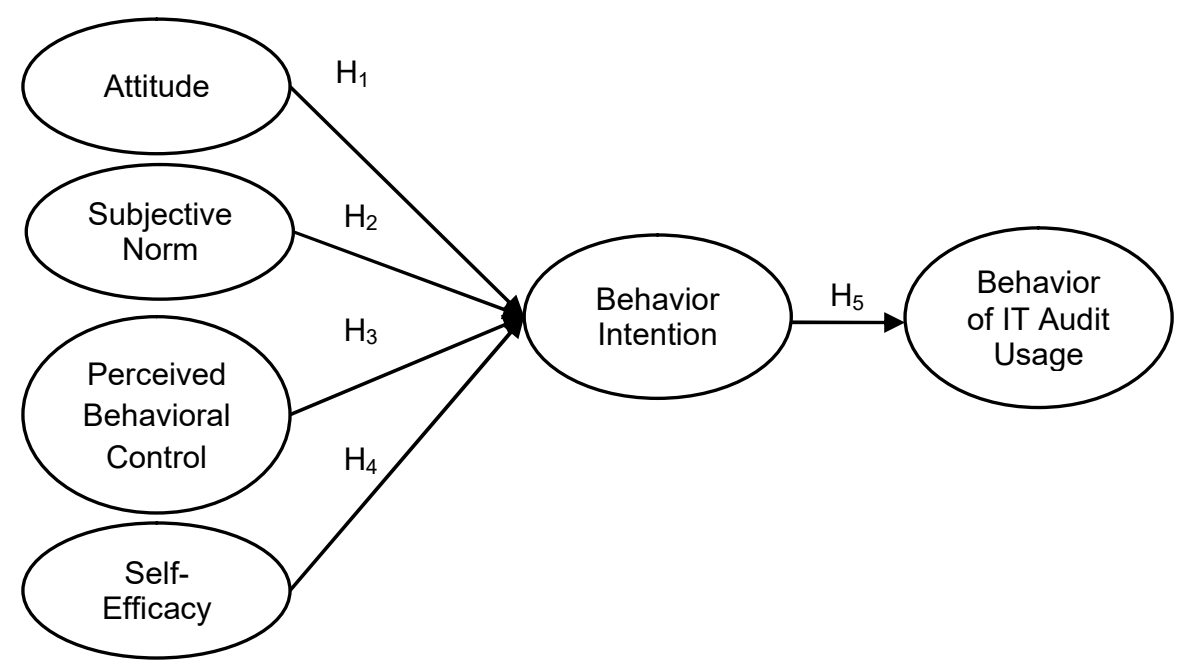

Figure 1 - Research Model

Subjective norm is defined as social norms or normative pressures that may affect the interests of individual behavior (Ajzen, 1991). Subjective norm also refers to the individual feeling that some of the important people around him or her can influence his or her behavior intention (Ajzen, 1991). Some studies (Ajzen, 1991, Armitage \& Conner, 2001; Baker \& White, 2010; Jafarkarimi et al., 2016; Kim et al., 2016; Cheung \& To, 2016) suggest that subjective norms have a positive effect on interest Individual behavior. Therefore, the second hypothesis is:

$\mathrm{H}_{2}$ : Subjective norm has positive influence towards behavior intention of auditor in using information technology for auditing

Perceived behavior control is defined as how easy or difficult certain behavior is started (Ajzen, 1991; Kim et al., 2016). Perceived behavior control will then indicate ease or difficulty of a person in taking action and is considered as a reflection of past experiences in dealing with obstacles and problems that have been anticipated. The perceived behavior control of a person depends on the extent to which it experiences internal constraints, which are reflected and felt inside (Lin, 2006; Nasri \& Charfeddin, 2012; Kim et al., 2016). Some studies (Armitage \& Conner, 2001; Baker \& White, 2010; Pavlou \& Fygenson, 2013; Jafarkarimi et al., 2016; Kim et al., 2016; Cheung \& To, 2016) suggest that perceived behavior control have positive influence towards behavior intention of an individual. Thus, the third hypothesis is:

$\mathrm{H}_{3}$ : Perceived Behavior Control has positive influence towards behavior intention of auditor in using information technology for auditing.

Self-efficacy is defined as a belief in one's ability to exert motivation, cognitive resources, and actions necessary to meet situational demands (Bandura, 1999). Such selfefficacy refers to beliefs about one's own ability to accomplish certain tasks with his or her own actions and resources amidst of obstacles or problems (Sniehotta, Scholz, and Schwarzer, 2005). Some studies (Compeau and Higgins 1995, Fu, Farn, and Chao, 2006; Lam, Cho, and Qu, 2007; Chen et al., 2013) suggest that there is positive relationship between self-efficacy and behavior intention of an individual. Thus, the fourth hypothesis is:

$\mathrm{H}_{4}$ : Self-efficacy has positive influence towards behavior intention of auditor in using information technology for auditing.

Davis, et. al (1989) explains that intention is a key indicator in the model of technology use. Ajzen (1991) assumes that intention is the factor of motivation that can influence a behavior through an indication of how hard an individual is willing to try, how much effort he or she planned to perform certain behavior. Several studies (Davis et al., 1989; Yilmaz \& Ozer, 2008; Venkatesh \& Davis, 2000; Kim et al., 2016) suggest that there is positive 
relationship between behavior intention and individual behavior. Based on the theories, the fifth hypothesis is:

$\mathrm{H}_{5}$ : Behavior intention has positive influence towards behavioral interest of auditor in using information technology for auditing.

\section{METHODS OF RESEARCH}

Samples. The samples were 102 auditors working in Big Four, a public accounting firm in Indonesia. The data collection method was survey and the instrument was in the form of questionnaire. The data collection method took place in December 2016.

Procedures. The data collection methods adopted the convenience sampling technique, selecting samples that facilitated researchers and the snowball sampling conducted by collecting samples from respondents who came from a network (Hartono, 2010: 99-100). Based on the theories, the researcher made confirmation to one of the respondents one month before the questionnaire was distributed. The researchers called one of the respondents from each of the public accounting firms asking his or her willingness to be the samples and then asking him or her to spread the news to the respondents. Having got the approval, the researchers sent the soft-copied version of the questionnaire. The softcopied version was in the form of google form link. The researchers sent different google form links to each accounting firm.

Measure and Research Instrument. The instrument used to analyze the data was the smartPLS. Previous research was used as reference ro decide which instruments used to measure each of the variables. Attitude (AT) adopted the four indicators from Taylor \& Todd (1995) and Bhattacherjee (2000)'s studies. Four indicators from Taylor \& Todd (1995) and Bhattacherjee (2000)'s studies were used to measure subjective norm (SN). Four indicators from Taylor \& Todd (1995) and Bhattacherjee (2000)'s studies were again used to measure Perceived Behavior Control (PBC). Three indicators of the instrument from the Taylor \& Todd (1995) and Bhattacherjee (2000)'s studies were used to measure Self-Efficacy (SE). Four indicators of the instrument from the Venkatesh \& Davis (2000)'s study were used to measure Behavior Intention $(\mathrm{BI})$. Behavior $(\mathrm{AB})$ was measured using three indicators of the instrument from the Kim, et. al (2016).

Each of them was measured using Likert scale from 1 (one) to 7 (seven). $1=$ strongly disagree, $2=$ disagree, $3=$ somewhat disagree, $4=$ neutral, $5=$ somewhat agree, $6=$ agree, $7=$ strongly agree.

\section{RESULTS OF STUDY}

Based on the position, most of the respondents $(21 \%)$ were junior auditor. There were more male respondents compared to female ones; the percentage of the male respondents was $62 \%$. The average respondents were between $20-30$ years old. $76 \%$ of the respondents had bachelor degree and $47 \%$ of them had been working for more than five years. Finally, $39 \%$ of the respondents had more than 5 years of experience as auditor. Table 1 described the characteristics of the samples.

The loading factors of all constructs were higher than 0.7, and the AVE scores and communality were higher than 0.5 . These showed that convergent calidity showed all latent variables. The cronbach alpha scores was higher than 0.6 and the composite reliability was higher than 0.7. These showed that all constructs had passed the reliability testing. Furthermore, Table 3 mentioned that the AVE root was higher than the latent variable correlation and the cross-loading was higher than 0.7. These showed all constructs had passed the discriminant validity testing.

The hypotheses were accepted when the original sample or beta $(\beta)$ value was positive and the t-statistic was higher than 1.64. $\mathrm{H} 1$ was accepted when attitudes had positive influence towards the auditor's behavior intntion in using information technology for auditing $(\beta=0.0819$; $t$-statistic 1.8617> 1.64). 
Table 1 - Sample Demographics

\begin{tabular}{|c|c|c|c|c|}
\hline No. & & Description & Frequency & Percentage \\
\hline \multirow[t]{4}{*}{1} & Position & Manager & 10 & $10 \%$ \\
\hline & & Supervisor & 24 & $23 \%$ \\
\hline & & Senior Auditor & 22 & $21 \%$ \\
\hline & & Junior Auditor & 48 & $46 \%$ \\
\hline \multirow[t]{2}{*}{2} & Sex & Male & 65 & $62 \%$ \\
\hline & & Female & 39 & $38 \%$ \\
\hline \multirow[t]{5}{*}{3} & Age & 20-30 years old & 61 & $59 \%$ \\
\hline & & $31-40$ years old & 25 & $24 \%$ \\
\hline & & $41-50$ years old & 18 & $17 \%$ \\
\hline & & $51-60$ years old & 0 & $0 \%$ \\
\hline & & $>60$ years old & 0 & $0 \%$ \\
\hline \multirow[t]{4}{*}{4} & Qualification & D3 (three-year diploma) & 0 & $0 \%$ \\
\hline & & S1 (bachelor degree) & 79 & $76 \%$ \\
\hline & & S2 (master's degree) & 22 & $21 \%$ \\
\hline & & S3 (doctorate degree) & 3 & $3 \%$ \\
\hline \multirow[t]{4}{*}{5} & Job Experience & $<1$ years & 20 & $19 \%$ \\
\hline & & $1<x \leq 3$ years & 29 & $28 \%$ \\
\hline & & $3<x \leq 5$ years & 6 & $6 \%$ \\
\hline & & $>5$ years & 49 & $47 \%$ \\
\hline \multirow[t]{3}{*}{6} & Experience in Using Information Technology & $<2$ years & 25 & $24 \%$ \\
\hline & for Auditing & $2<x \leq 5$ years & 38 & $37 \%$ \\
\hline & & $>5$ years & 41 & $39 \%$ \\
\hline
\end{tabular}

Table 2 - Confirmatory factor analysis results for measurement model

\begin{tabular}{|c|c|c|c|c|c|c|c|}
\hline Constructs & Items & $\begin{array}{l}\text { Original } \\
\text { Sample }\end{array}$ & $\begin{array}{l}\mathrm{T} \\
\text { Statistics }\end{array}$ & AVE & Communality & $\begin{array}{l}\text { Cronbach } \\
\text { Alpha }\end{array}$ & $\begin{array}{l}\text { Composite } \\
\text { Reliability }\end{array}$ \\
\hline \multirow{4}{*}{ Attitude (AT) } & AT1 & 0.7762 & 34.9957 & 0.6241 & 0.6241 & 0.8037 & 0.8685 \\
\hline & AT2 & 0.703 & 28.498 & & & & \\
\hline & AT3 & 0.8184 & 60.5087 & & & & \\
\hline & AT4 & 0.8543 & 64.9725 & & & & \\
\hline \multirow{4}{*}{ Subjective Norm (SN) } & SN1 & 0.8051 & 71.401 & 0.6865 & 0.6865 & 0.8474 & 0.8974 \\
\hline & SN2 & 0.8307 & 64.2162 & & & & \\
\hline & SN3 & 0.8814 & 107.2005 & & & & \\
\hline & SN4 & 0.7942 & 39.607 & & & & \\
\hline \multirow{4}{*}{$\begin{array}{l}\text { Perceived Behavior } \\
\text { Control (PBC) }\end{array}$} & PBC1 & 0.8304 & 88.1354 & 0.6907 & 0.6907 & 0.8504 & 0.8992 \\
\hline & PBC2 & 0.8408 & 73.112 & & & & \\
\hline & PBC3 & 0.8569 & 85.7625 & & & & \\
\hline & PBC4 & 0.7949 & 40.9952 & & & & \\
\hline \multirow{3}{*}{ Self-efficacy (SE) } & SE1 & 0.9035 & 118.9345 & 0.7878 & 0.7878 & 0.8686 & 0.9176 \\
\hline & SE2 & 0.8825 & 73.1332 & & & & \\
\hline & SE3 & 0.8765 & 116.1874 & & & & \\
\hline \multirow{4}{*}{ Behavior Intention (BI) } & $\mathrm{Bl} 1$ & 0.8658 & 104.4145 & 0.6711 & 0.6711 & 0.8371 & 0.8903 \\
\hline & $\mathrm{BI} 2$ & 0.8753 & 100.5478 & & & & \\
\hline & $\mathrm{BI} 3$ & 0.8101 & 79.0104 & & & & \\
\hline & $\mathrm{B} 14$ & 0.7157 & 30.3849 & & & & \\
\hline \multirow{3}{*}{ Actual Behavior (AB) } & AB1 & 0.909 & 139.8361 & 0.7664 & 0.7664 & 0.8509 & 0.9075 \\
\hline & AB2 & 0.8095 & 59.0113 & & & & \\
\hline & AB3 & 0.9042 & 106.2134 & & & & \\
\hline
\end{tabular}

Table 3 - AVE Root of Latent Variable Correlation

\begin{tabular}{llllllll}
\hline Constructs & AVE Root & 1 & 2 & 3 & 4 & 5 \\
\hline 1 & Attitude & 0.7900 & 1 & 0 & 0 & 0 & 0 \\
2 & Subjective Norm & 0.8286 & 0.8565 & 1 & 0 & 0 & 0 \\
3 & Perceived Behavior Control & 0.8311 & 0.8039 & 0.9618 & 1 & 0 & 0 \\
4 & Self-efficacy & 0.8876 & 0.5651 & 0.495 & 0.4867 & 1 & 0 \\
5 & Behavior Intention & 0.8192 & 0.5846 & 0.6319 & 0.619 & 0.4566 & 1 \\
6 & Actual Behavior & 0.8754 & 0.4378 & 0.4302 & 0.4131 & 0.5279 & 0.4787 \\
\hline
\end{tabular}

H2 was accepted when the subjective norm had positive influence towards the auditor's behavior intention in using information technology for auditing ( $\beta=0.3344$; $t$-statistic $6.0374>1.64)$. $\mathrm{H} 3$ was accepted when the perceived behavior control had positive influence towards the auditor's behavior intention in using information technology for auditing $(\beta=0.1473$; t-statistic 3.8617> 1.64). $\mathrm{H} 4$ was accepted when self-efficacy had positive influence towards the auditor's behavior intention in using information technology for auditing ( $\beta=0.173$; t-statistic 5.3843> 1.64). H5 was accepted when behavior intention had positive 
influence towards auditor behavior in using information technology for auditing ( $\beta=0.4787$; $\mathrm{t}$ statistic 13.3083>1.64).

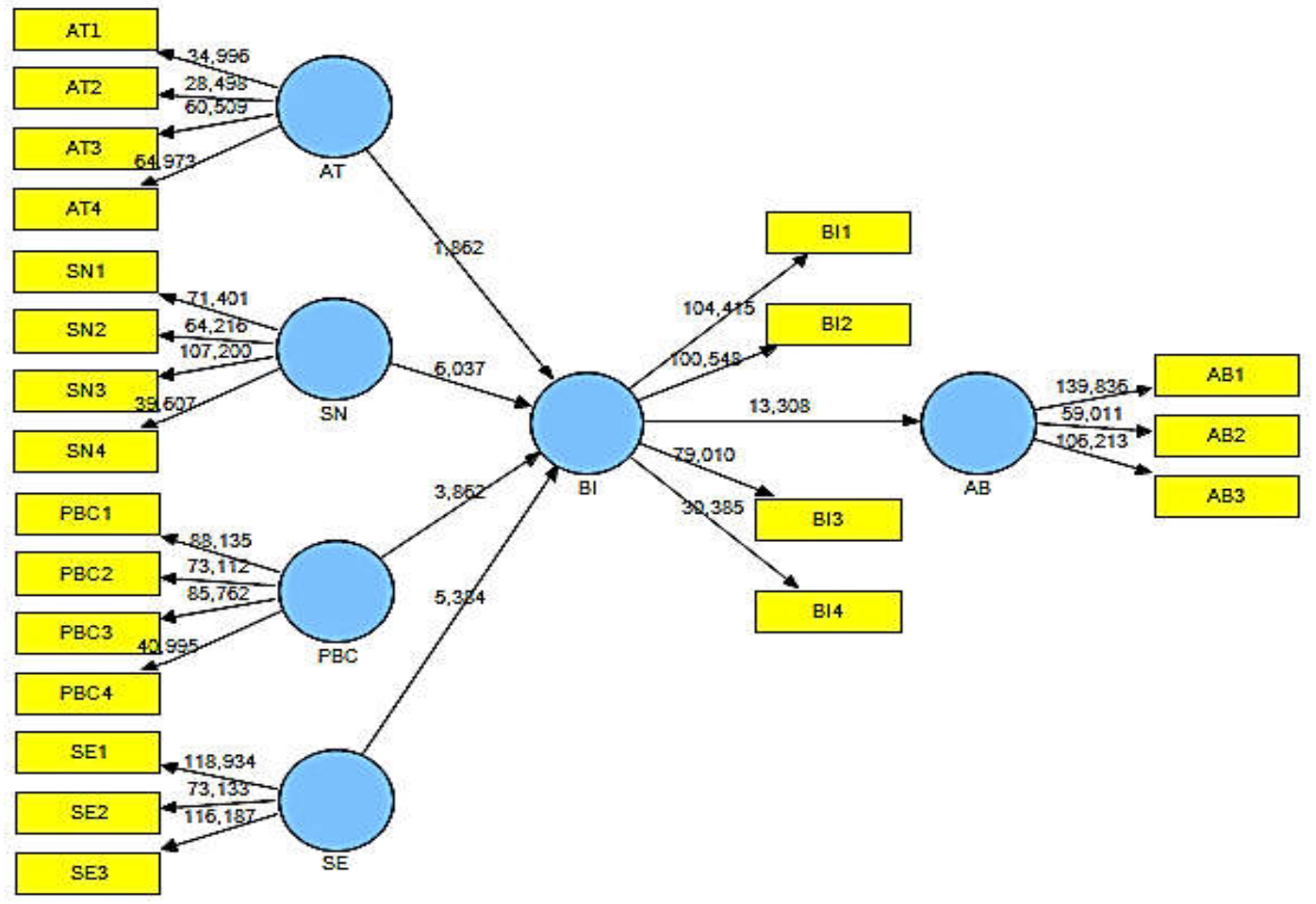

Figure 2 - Results of structural modeling analysis

Table 4 summarized the result of the hypothesis testing.

Table 4 - Hypothesis Testing Result

\begin{tabular}{lllll}
\hline Hypothesis & Construct & Original Sample & T Statistics & Result \\
\hline H1 & Attitude -> Behavior Intention & 0.0819 & 1.8617 & Accepted \\
H2 & Subjective Norm -> Behavior Intention & 0.3344 & 6.0374 & Accepted \\
H3 & Perceived Behavior Control -> Behavior Intention & 0.1473 & 3.8617 & Accepted \\
H4 & Self-efficacy -> Behavior Intention & 0.173 & 5.3843 & Accepted \\
H5 & Behavior Intention -> Actual Behavior & 0.4787 & 13.3083 & Accepted \\
\hline
\end{tabular}

\section{DISCUSSION OF RESULTS}

The study adopted the TPB and SCT theories to explain the use of information technology for auditing by auditors in Indonesia. The findings showed that attitude had positive influence towards auditor's behavior intention in using information technology for auditing. The findings corroborate to the previous studies conducted by Baker \& White (2010), Jafarkarimi, et. al (2016), Kim, et. al (2016), Cheung \& To (2016). The more positive attitude the auditors had, the higher their intention was and therefore the more likely he or she was in using information technology for auditing. The study also showed the subjective norm had positive influence towards the auditor's behavior intention in using information technology for auditing. It is in line with the findings of Lam, Cho, \& Qu (2007), Kim, et. al (2016), Armitage \& Conner (2001), Baker \& White (2010), Jafarkarimi, et. al (2016), Cheung \& To (2016)'s studies. Social pressure from superintendents, head of accounting firm, colleagues or fellow auditor may influence the use of information technology for auditing. The study showed that perceived control behavior had positive influence towards the auditor's behavior intention in using information technology for auditing. It is in line with the findings of the previous studies conducted by Pavlou \& Fygenson (2013), Jafarkarimi, et. al (2016), Kim, et. al (2016), and Cheung \& To (2016). The fact that the perceived behavior control also had 
positive influence towards the auditor's behavior intention in using information technology for auditing may be stemmed from how easy and user-friendly an auditing software or application is.

Furthermore, the study also revealed that self-efficacy had positive influence towards the the auditor's behavior intention in using information technology for auditing. Self-efficacy is derived from SCT. The findings corroborate to those of Hsu \& Chiu (2004), Fu, Farn, \& Chao (2006), Lam, Cho, \& Qu (2007), Sniehotta, Scholz, \& Schwarzer (2005), Chen, et. a. (2013). When an auditor is certain that he or she is able to apply information technology, more particularly one for auditing, the auditor will use the software or application easily. As an addition, it also showed that behavior intention had positive influence towards auditor's behavior in using information technology for auditing. It is in line with Venkatesh \& Davis (2000), Yilmaz and Ozer (2008), Cheng, Chen, \& Yen (2015), Jafarkarimi, et. al (2016), and Kim, et. al (2016)'s studies. High behavior intention to use information technology for auditing will result in implementation of the technology in auditor's actual work.

Implications. The results of this study have two implications, theoretical implications and practical implications. The theoretical implications of this study are the results of this study support the Theory of Planned Behavior (TPB) and Social Cognitive Theory (SCT) theories. Besides supporting both theories, the study is also able to develop the concept of acceptance or rejection of a technology by using attitude constructs, subjective norms, perceptions of behavioral control, self-belief, behavioral interests, and behavior. The behavior intention in the study functions as the mediating variable.

The practical implication is the study can be used as a reference in taking considering in designing and developing information technology in general and information technology for auditing in particular. Practitioners and developers of information technology for auditing who experience difficulties in designing and developing information technology for auditing can take the six factors above into account in evaluating auditor's behavior intention and eventually their behavior in using information technology for auditing. In addition, another implication is that the study can be used as reference for decision-making support or policies related to management and finance in public accounting firm related to the use of information technology for auditing. Public accounting firm may also use the study to motivate auditors that information technology for auditing improves their performance and ability to compete against foreign public accounting firm.

\section{CONCLUSION}

The study aims at examining the factors that influence behavior intention towards auditor behavior in using information technology for auditing using the TPB and SCT models. Survey is conducted and soft-copied version of the questionnaires in the form of google form links is distributed. The total respondents are 102 auditors working in The Big Four Public Accounting Firm.

The results of the study conclude that auditor's behavior in using information technology for auditing is determined by his or her behavior intention. Usefulness, attitudes, subjective norms, perceived behavior control, and self-efficacy have positive influence towards the auditor's behavior intention. In addition, subjective norms have a more dominant influence towards the auditor's behavior intention than attitudes, perceived behavior control, and self-efficacy. The result reveals that behavior intention is a major determinant of behavior and is a mediating variable. Behavioral intention indicates that the auditor has a positive evaluation towardsthe auditor's behavior in using information technology for auditing.

\section{REFERENCES}

1. Ajzen, I. (1985). From intentions to actions: a theory of planned behavior. (pp. 11e39). Berlin Heidelberg: Springer.

2. Ajzen, I. (1991). The theory of planned behavior. Orgnizational Behavior and Human Decision Processes, 50, 179e211. 
3. Armitage, C. J., \& Conner, M. (2001). Efficacy of the theory of planned behaviour: a meta-analytic review. British Journal of Social Psychology, 40(4), 471e499.

4. Baker, R. K., \& White, K. M. (2010). Predicting adolescents' use of social networking sites from an extended theory of planned behaviour perspective. Computers in Human Behavior, 26(6), 1591e1597.

5. Bandura, A. (1986). Social Foundations of Thought and Action: A Social Cognitive Theory. Prentice-Hall, NJ: Englewood Cliffs.

6. Bandura, Albert. (1999). Social Cognitive Theory: An Agentic Perspective. Journal of Business Ethics, Vol. 61, No. 2 (Oct., 2005), pp. 165-181.

7. Beck, L., \& Ajzen, I. (1991). Predicting dishonest actions using the theory of planned behavior. Journal of Research in Personality, 25(3), $285 \mathrm{e} 301$.

8. Bhattacherjee, Anol. (2000). Acceptance of Internet Aplications Services: The Case of Electronic Brokerages. IEEE Transactions on Systems, Man, and Cybernetices- Part A : Systems and Humans 30 (4) 411-420.

9. Chen, Yi-Cheng, Yi-Chien Lin, Ron Chuen Yeh, \& Shi-Jer Lou. (2013). Examining Factors Affecting College Students' Intention to Use Web-Based Instruction Systems: Towards An Integrated Model. TOJET: The Turkish Online Journal of Educational Technology, volume 12 Issue 2.

10. Cheung, Millissa F.Y. \& W.M. To. 2016. Service Co-creation in Social Media: An Extension of The Theory of Planned Behavior. Human Behavior, 65 (2016) 260e266.

11. Compeau, D. R. \& Higgins, C. A. (1995). Computer Self Efficacy: Development Of A Measure And Initial Test. Management Information Systems Quarterly, Vol. 19, No. 2, pp. 189-211.

12. Curry, J. R. (2002). The organizational challenge: IT and revolution in higher education. Educause Review, 37(2), 40-48.

13. Damasiotis, Vyron, Panagiotis Trivellas, Ilias Santouridis, Sotiris Nikolopoulos, \& Evdokia Tsifora. (2015). IT Competences for Professional Accountants. A Review. ProcediaSocial and Behavioral Sciences, 175 (2015) 537-545.

14. Davis, Fred D., Richard P Bagozzi, \& Warshaw Paul R. (1989). User Acceptance of Computer Technology: A Comparison of Two Theoretical Models. ABI/Inform Global. Management Science, 982.

15. Fu, Jen-Ruei, Cheng-Kiang Farn, \& Wen-Pin Chao. (2006). Acceptance of Electronic Tax Filing: A Study of Taxpayer Intentions. Elseiver, Information and Management, 43 (2006) 109-126.

16. Hartono, J. (2010). Metodologi Penelitian Bisnis: Salah Kaprah \& PengalamanPengalaman. Yogyakarta: C.V. Andi Offset.

17. Havelka, D. \& Jeffrey W. Merhout. (2013). Internal Information Technology Audit Process Quality: Theory Development Using Structured Group Processes. International Journal of Accounting Information Systems, 14 (2013) 165-192.

18. Hsu, Meng-Hsiang \& Chao-Min Chiu. (2004). Internet Self-Efficacy and Electronic Service Acceptance. Elseiver, Decision Support Systems, 38 (2004) 369- 381.

19. IFAC. (2006a). Proposed International Educational Practice statement 2.1 (IEPS 2.1). Information Technology for Professional Accountants. International Federation of Accountants (IFAC) Available at: http://www.ifac.org/sites/default/files/meetings/files/3109.pdf.

20. Jafarkarimi, Hosein, Robab Saadatdoost, Alex Tze Hiang Sim, \& Jee Mei Hee. (2016). Behavioral Intention in Social Networking Sites Ethical Dilemmas: An Extended Model Based on Theory of Planned Behavior. Computers in Human Behavior, 62 (2016) $545 \mathrm{e} 561$.

21. Kim, Eunice, Jung-Ah Lee, Yongjun Sung, \& Sejung Marina Choi. (2016). Predicting selfie-posting behavior on social networking sites: An extension of theory of planned behavior. Computers in Human Behavior, 62 (2016) 116e123.

22. Kim, Hyo-Jeong, Michael Mannino, \& Robert J. Nieschwietz. (2009). Information technology acceptance in the internal audit profession: Impact of technology features and complexity. International Journal of Accounting Information Systems 10 (2009) 214-228. 
23. Lam, Terry., Vincent Cho, \& Hailin Qu. (2007). A Study Of Hotel Employee Behavioral Intentios Woward Adption Of Information Technology. International Journal of Hospitality Management, 26,9-65.

24. Lin, H. F. (2006). Understanding behavioral intention to participate in virtual communities. Cyber Psychology \& Behavior, 9(5), 540e547.

25. Nasri, Wadie \& Lanouar Charfeddine. 2012. Factors Affecting the Adoption of Internet Banking in Tunisia: An Integration Theory of Acceptance Model And Theory of Planned Behavior. Journal of High Technology Management Research, 23, pp. 1-14.

26. Pavlou, Paul A. \& Mendel Fygenson. 2006. Understanding and Predicting Electronic Commerce Adoption: An Extension of the Theory of Planned Behavior. MIS Quarterly, Vol. 30, No. 1, pp. 115-143.

27. Sniehotta, Falko F., Urte Scholz, \& Ralf Schwarzer. 2005. Bridging the intentionbehaviour gap: Planning, Self-efficacy, and Sction Control in the Adoption and Maintenance of Physical Exercise. Psychology and Health Journal, 20, pp. 143-160.

28. Stoel, Dale, Douglas Havelka, \& Jeffrey W. Merhout. (2012). An Analysis of Attributes that Impact Information Technology Audit Quality: A Study of IT And Financial Audit Practitioners. International Journal of Accounting Information Systems, 13 (2012) 60-79.

29. Sugiarsono, Joko. 2003. Sajian Utama, Potret Kebingungan Investasi TI. SWA, Edisi 02/XIX/23 Januari - 5 Februari 2003. P. $24-31$.

30. Taylor, Shirley \& Peter A. Todd. (1995). Understanding Information Technology Usage: A Test of Competing Models. Institude for Operations Research and Management Sciences. Information Systems Research, 6:2.

31. Yilmaz, E. \& Ozer, G., 2008. Information Technology Usage of Accountants. 1st International Conference on Menagement and Economics "Current Issues in Emerging Eco nomics in Global Perspective". Vol. 2, pp. 318-334.

\section{APPENDIX - QUESTIONNAIRE}

\begin{tabular}{|c|c|c|c|c|c|c|c|c|}
\hline No. & Statement & SD & $\mathrm{D}$ & SwD & $\mathrm{N}$ & SwA & A & $\mathrm{SA}$ \\
\hline \multicolumn{9}{|c|}{ Attitude } \\
\hline AT1 & $\begin{array}{l}\text { Using information technology for auditing to complete auditing process is a } \\
\text { good idea. }\end{array}$ & 1 & 2 & 3 & 4 & 5 & 6 & 7 \\
\hline АT2 & $\begin{array}{l}\text { Using information technology for auditing to complete auditing process is a } \\
\text { wise decision. }\end{array}$ & 1 & 2 & 3 & 4 & 5 & 6 & 7 \\
\hline AT3 & $\begin{array}{l}\text { I like the idea of using information technology for auditing to complete } \\
\text { auditing process. }\end{array}$ & 1 & 2 & 3 & 4 & 5 & 6 & 7 \\
\hline AT4 & $\begin{array}{l}\text { Using information technology for auditing to complete auditing process may } \\
\text { become a positive experience }\end{array}$ & 1 & 2 & 3 & 4 & 5 & 6 & 7 \\
\hline \multicolumn{9}{|c|}{ Subjective Norm } \\
\hline SN1 & Superintendent thinks that I have to use information technology for auditing. & 1 & 2 & 3 & 4 & 5 & 6 & 7 \\
\hline SN2 & Decision-maker thinks that I have to use information technology. & 1 & 2 & 3 & 4 & 5 & 6 & 7 \\
\hline SN3 & Colleagues/ fellow auditors would favor me using information technology. & 1 & 2 & 3 & 4 & 5 & 6 & 7 \\
\hline SN4 & Superintendent thinks that using information technology is a good idea. & 1 & 2 & 3 & 4 & 5 & 6 & 7 \\
\hline \multicolumn{9}{|c|}{ Perceived Behavior Control } \\
\hline PBC1 & I think I will be able to use information technology for auditing. & 1 & 2 & 3 & 4 & 5 & 6 & 7 \\
\hline PBC2 & I think I have full control in using information technology for auditing. & 1 & 2 & 3 & 4 & 5 & 6 & 7 \\
\hline PBC3 & I have resource in using information technology for auditing. & 1 & 2 & 3 & 4 & 5 & 6 & 7 \\
\hline PBC4 & I have competence and skills to use information technology for auditing. & 1 & 2 & 3 & 4 & 5 & 6 & 7 \\
\hline \multicolumn{9}{|c|}{ Self-Efficacy } \\
\hline SE1 & I am comfortable of using my own information technology for auditing. & 1 & 2 & 3 & 4 & 5 & 6 & 7 \\
\hline SE2 & I will use and run my own information technology for auditing. & 1 & 2 & 3 & 4 & 5 & 6 & 7 \\
\hline SE3 & $\begin{array}{l}\text { I have suffiecient information for using/ running my own information } \\
\text { technology for auditing. }\end{array}$ & 1 & 2 & 3 & 4 & 5 & 6 & 7 \\
\hline \multicolumn{9}{|c|}{ Behavior Intention } \\
\hline $\mathrm{BI} 1$ & I want to keep using information technology for auditing in the future. & 1 & 2 & 3 & 4 & 5 & 6 & 7 \\
\hline $\mathrm{BI} 2$ & I hope I can keep using information technology for auditing in the future.. & 1 & 2 & 3 & 4 & 5 & 6 & 7 \\
\hline $\mathrm{BI} 3$ & I will advise other people to use information technology for auditing. & 1 & 2 & 3 & 4 & 5 & 6 & 7 \\
\hline $\mathrm{BI} 4$ & I add information technology for auditing as facilities I prefer & 1 & 2 & 3 & 4 & 5 & 6 & 7 \\
\hline \multicolumn{9}{|c|}{ Actual Behavior } \\
\hline AB1 & I frequently use information technology for auditing at work. & 1 & 2 & 3 & 4 & 5 & 6 & 7 \\
\hline AB2 & I always use information technology for auditing at work. & 1 & 2 & 3 & 4 & 5 & 6 & 7 \\
\hline AB3 & I use information technology for auditing once a day. & 1 & 2 & 3 & 4 & 5 & 6 & 7 \\
\hline
\end{tabular}

Description: $S D=$ Strongly Disagree; $D=$ Disagree; $S w D=$ Somewhat Disagree; $N=$ Neutral; $S w A=$ Somewhat; $A=A g r e e$; $S A=$ Strongly Agree . 